\title{
SPECIFICATIONS FOR NATIONAL FLOUR
}

$\mathrm{T}$ HE Accessory Food Factors Committee of the Lister Institute and the Medical Research Council, in a memorandum issued in the summer of 1940, recommended the adoption for bread of a flour of 80-85 per cent extraction of the wheat, in the following terms: "Flour for the bread of the people should contain the germ of the wheat grain, as much as possible of the aleurone layer, and the finer portions of the bran. Instead of flour consisting of aboüt 70 per cent of the wheat grain, as it does at present, the percentage extracted should be at least 80 to 85 per cent".*

Since this recommendation was made, the Ministry of Food has decided to make generally available to the public bread baked from flour of 85 per cent extraction.

In the original memorandum the nutritional considerations on which the recommendation was based were set out. It now seems desirable to re-state them, incorporating the results of further research and defining more exactly the character of the particular 85 per cent extraction flour recommended by the Committee.

\section{Special Nutritive Properties of the Selected FLOUR}

The degree of extraction was fixed at 85 per cent in order to secure a flour which should contain :

(1) As much as possible of the $B$ vitamins including riboflavin and nicotinic acid and especially of vitamin $B_{1}$, present in the whole wheat.

(2) As much protein as possible, including a high proportion of that situated in the outer layers of the grain. This protein is known to possess a higher nutritive value than that contained in white flour.

(3) As little bran as possible so that there should be no risk of loss of nutritive value due to presence of much indigestible material. War-time diets already contain much vegetable food with relatively large amounts of roughage; it is undesirable to increase this further.

\section{Production of Flour of 85 PER CENT EXTRACTION}

Flour of 85 per cent extraction can in practice be obtained by two general methods : (1) by rearrangement of the milling machinery to produce a flour containing 85 per cent of the wheat, or (2) by addition to the white flour (73 per cent extraction), obtained in the ordinary milling processes, of combinations of the other fractions of the wheat.

The consideration which has influenced the final

*See also NATURE, 146, 117 (1940). selection of the flour to be adopted has been the need to combine two qualities: first, the best nutritive value and, secondly, the production of a loaf as little removed as possible in colour, texture and flavour from that of ordinary white bread. Two flours, prepared respectively by the above methods (1) and (2) were selected as possessing equal nutritive value, the first, however, being preferable as fulfilling the second condition most perfectly. Flour (1) was selected as the best for the following reasons :

(a) Of all flours obtained at the same level of extraction by different methods from the same grist, it had the highest vitamin B content and in this respect closely approached that usually accepted for wholemeal bread.

(b) It had the lowest fibre content compared with other flours extracted at this level from the same grist.

(c) Of all the breads tested, baked from 85 per cent flour, it yielded the one which resembled white bread most closely in flavour and texture.

(d) The colour of the bread was pale brown and was not unattractive.

(e) On technical and on æsthetic grounds the loaf baked from it was considered excellent.

\section{DEFINITIONS FOR TWO SELECTED FLOURS}

Flour (1).-This straight-run flour may be defined as a flour containing 85 per cent by weight of the clean wheat, in which is included $(a)$ the maximum amount of the germ and of the aleurone layer and $(b)$ the minimum of the pericarp, as shown by its low fibre content.

Flour (2).-May be defined as $(a)$ containing 85 per cent of the weight of the clean wheat grain in which is included all the white flour, all the reduction roll tails, mill finish and purifier tails and sufficient fine bran to bring the amount of the mixture up to 85 per cent of the clean wheat; (b) containing 85 per cent of the clean wheat and excluding 15 per cent consisting of the bran and pollards.

Analyses of samples of flours (1) and (2) are set out in the accompanying table below, with those of white flour of 73 per cent extraction and of wholemeal flour, all four materials being derived from the same grist (water content being 15 per cent).

Samples of flours (1) and (2), obtained from the same grist, were found to be similar in content of protein, ash and vitamin $B_{1}$, which in both cases was more than 1 I.U. per gm. (thiochrome methods) The fibre content of both flours was less than 0.9 


\begin{tabular}{|c|c|c|c|c|c|c|c|}
\hline \multirow[b]{2}{*}{ Flour } & \multirow[b]{2}{*}{$\underset{\%}{\text { Fibre }}$} & \multirow[b]{2}{*}{$\underset{\%}{\text { Ash }}$} & \multirow{2}{*}{$\begin{array}{l}\text { Pro- } \\
\text { tein } \\
\%\end{array}$} & \multirow{2}{*}{$\begin{array}{l}\text { Vitamin } B_{1} \\
\text { International } \\
\text { Units per gm. } \\
\text { (thiochrome } \\
\text { method). }\end{array}$} & \multirow{2}{*}{$\begin{array}{c}\text { Cal- } \\
\text { cium } \\
\text { mgm. } \\
\%\end{array}$} & \multicolumn{2}{|c|}{$\begin{array}{l}\text { Phosphorus } \\
\text { mgno\% }\end{array}$} \\
\hline & & & & & & Total & $\begin{array}{c}\text { As } \\
\text { phytic } \\
\text { acid. }\end{array}$ \\
\hline $1(85 \%)$ & $0 \cdot 60$ & 0.90 & $11 \cdot 4$ & $1 \cdot 2$ & 27 & 203 & 123 \\
\hline $2(85 \%)$ & 0.85 & 0.94 & $11 \cdot 5$ & $1 \cdot 15$ & 27 & 211 & 128 \\
\hline $\begin{array}{l}\text { White } \\
(73 \%)\end{array}$ & $\begin{array}{l}0 \text { to } \\
0.20\end{array}$ & $0 \cdot 46$ & $10 \cdot 6$ & $0 \cdot 35$ & 15 & 101 & 35 \\
\hline $\begin{array}{c}\text { Whole- } \\
\text { meal } \\
(100 \%)\end{array}$ & $1 \cdot 8$ & $1 \cdot 51$ & $11 \cdot 9$ & 1.4 & 36 & 343 & 246 \\
\hline
\end{tabular}

per cent that of flour (1) being lower than that of flour (2). The lower the fibre content the better is the flour and the more efficient is the milling.

\section{KEEPING Properties}

No exact evidence is as yet available regarding the keeping properties of the particular types of flour selected, but from the experience gained of other brown and wholemeal flours there is little doubt that this flour of 85 per cent extraction could be kept in good state under reasonable conditions of storage for 4-6 weeks or longer.

\section{RECOMMENDATION I}

The Accessory Food Factors Committee, at its meeting on January 23, 1941, recommended that a flour of 85 per cent extraction (similar to flour (1) ) should be adopted.

Since modification of ordinary milling machinery would be required for production of flour (1) and this would take time, it was further recommended that a flour of 85 per cent extraction (similar to flour (2) should be adopted in the meantime, as this could be produced without any delay. The flour should not contain less than $I$ r.J. vitamin $B_{1}$ per gm. and the fibre should be less than 0.9 per cent (assuming a water content of 15 per cent).

\section{Addition of Calcium Salts}

It is known that the intake of calcium salts in the diets of Great Britain, especially among the poorer classes, is frequently below the minimum accepted. by nutrition experts as necessary for satisfactory growth of bones and teeth in growing children and for maintenance of the bones in adults. The addition of calcium salts to bread was recommended in the previous memorandum issued by the Medical Research Council. It is now possible to add details concerning the amounts required.

Wholemeal bread and bread made from flour of 85 per cent extraction contain more calcium than white bread and also more phosphorus. A large proportion of the phosphorus, however, is present in a combination (phytic acid) in which it is not directly available to the organism and at the same time diminishes the availability of the calcium present in the bread and in the rest of the diet. Recent tests made on human subjects for the
Medical Research Council have shown that to maintain a sufficient supply of calcium salts for health more calcium salts must be added to the diet. The most convenient way to do this is to add calcium carbonate to the wheat flour used for bread. As a result of the above tests on human subjects who consumed about one half of their total calorie intake as bread with only small amounts of milk and very little cheese, it has been calculated that additions are needed of $65 \mathrm{mgm}$. calcium per $100 \mathrm{gm}$. white flour $(7 \mathrm{oz}$. of calcium carbonate as creta prceparata B.P. per 280-lb. sack) and of $130 \mathrm{mgm}$. calcium per $100 \mathrm{gm}$. flour of 85 per cent extraction (14 oz. calcium carbonate per sack). In the case of the 85 per cent extraction flour the extra $7 \mathrm{oz}$. per sack is requìred to neutralize the effect of the extra phytic acid contained in flour of this degree of extraction.

It has long been a practice in baking to add similar amounts of substances known as 'improvers' (for example, acid calcium phosphate $12 \mathrm{oz}$. per sack, or up to $4 \frac{1}{2} \mathrm{lb}$. per sack, in case of certain self-raising flours at present on the market).

The addition of the recommended amounts of calcium carbonate to flour has no effect on the vitamin $B_{1}$ content of the flour or on its baking properties.

\section{RECOMMENDATION 2}

It is recommended that calcium carbonate (as creta proparata B.P.) should be added to the wheat flour from which white bread is made in the proportions of $7 \mathrm{oz}$. per sack $(280 \mathrm{lb}$.) of white flour and of $14 \mathrm{oz}$. per sack of 85 per cent extraction flour.

\section{ADdition of Iron Salts}

The desirability of adding iron in some form to flour has been considered, the reason being that anæmia due to insufficient iron in the diet is common in Great Britain and could easily and cheaply be prevented by administration of simple ferrous salts. A study of the available data on this subject has, however, led to the conclusion that the presence of added iron salts in flour might cause destruction of some of the other nutrients present. It is, therefore, not recommended that any such additions be made until further knowledge on this point is available.

\section{ADdiTION OF 'IMPROVERS'}

The addition of certain' 'improvers' to bread baked from flour of high extraction facilitates the work of the baker and results in a more attractive loaf. Such evidence as is available does not justify at this stage the prohibition of their use in the baking industry and the question has therefore been left open. 